\title{
Analysis of The Effect of Gross Domestic Product, Exchange Rate, and Inflation on Balance of Payments in Indonesia
}

\author{
Shinta Arida Hutagalung \\ Faculty of Economics, \\ Universitas Negeri Medan, Indonesia \\ Muhammad Fitri Rahmadana \\ Faculty of Economics, \\ Universitas Negeri Medan, Indonesia \\ Muhammad Nasir \\ Faculty of Economics, \\ Universitas Negeri Medan, Indonesia \\ Muammar Rinaldi \\ Faculty of Economics, \\ Universitas Negeri Medan, Indonesia
}

\begin{abstract}
This study aims to analyze the effect of the short and long term gross domestic product, exchange rate, and inflation on Indonesia's balance of payments. The data used in this study are secondary data which is obtained indirectly with the period of 1995 to 2015. Data sources were obtained from Bank Indonesia and the Central Bureau of Statistics. The data collection method used in this study with the indirect method is documentation through recording or copying data from Bank Indonesia and the Central Bureau of Statistics. The analysis model used is Error Correction Mechanism (ECM). The results of this study indicate that the regression model of the Autoregressive Distributed Lag Model (ARDL) for the long term and Error Correction Model (ECM) regarding the effect of independent variables such as Interest Rates, Gross Domestic Product and Inflation Against the Dependent dependent variable in Indonesia, then it can some conclusions are presented, namely from several independent variables that are tried and included in the savings equation in Indonesia using the Autoregressive Distributed Lag Model (ARDL) for the long term and Error Correction Model (ECM) for the short term, namely the gross domestic product variable, the inflation rate, and exchange rate. In the long run there are 2 (two) significant variables, namely gross domestic product and the exchange rate. While inflation is not significant. For the short term, there is 1 (one) significant variable, namely the exchange rate. Thus, only exchange rate variables are significant in both the short and long term. With only 1 (one) significant independent variable both in the long term and short term, it can be concluded that the exchange rate in the long term and short term is the main determining factor that affects the Balance of Payments in Indonesia. In the long run, Independent variables such as Gross Domestic Product and the exchange rate on the dependent variable Balance of Payments in Indonesia have a significant effect on the dependent variable Balance of Payments. Whereas in the short run, the exchange rate variable has a significant effect, and for other independent variables such as the GDP variable and the inflation rate does not have a significant effect.
\end{abstract}

Keywords: Gross domestic product, exchange rate, inflation, balance of payments 


\section{INTRODUCTION}

The economic condition of a country can be seen from the development of the balance of payments which informs about the condition of the economy. Information from the balance of payments can give an idea of how much the flow of sources of funds between one country and another country so that it is seen whether the country is an exporter of goods and capital, or vice versa. The balance of payments also has information about a country's foreign debt problems. The balance of payments, which is a sum of the current account and capital account, continues to experience changes before and after the economic crisis. These changes can be seen from the value and direction of the composition of the balance of payments that shows a different phenomenon.

Basri (2010) defines the balance of payments as an overview of all economic transactions between residents of a country (residents) and residents of other countries (non-residents) that are arranged systematically in a certain period. Indonesia's balance of payments has a vital role in managing the macroeconomy in Indonesia. Besides, the balance of payments can be used as a benchmark in measuring the ability of an economy, especially those relating to debt payment obligations and export-import transactions. The balance of payments can also be one indicator that influences the actions of market participants, along with several quantities in it and plays an essential role in making a country's income. Thus, the balance of payments is a sector that plays a vital role in efforts to encourage economic recovery in the country.

The balance of payments is beneficial because it can show the structure and composition of economic transactions and the international financial position of a country. International financial institutions such as the IMF, World Bank, and donor countries also use the balance of payments as one indicator in considering providing financial assistance to a country. The balance of payments is also one of the fundamental economic indicators of a country in addition to other macroeconomic variables.

\section{Figure. 1: Indonesia's Balance of Payments in 2006 - 2015 (billions of dollars)}

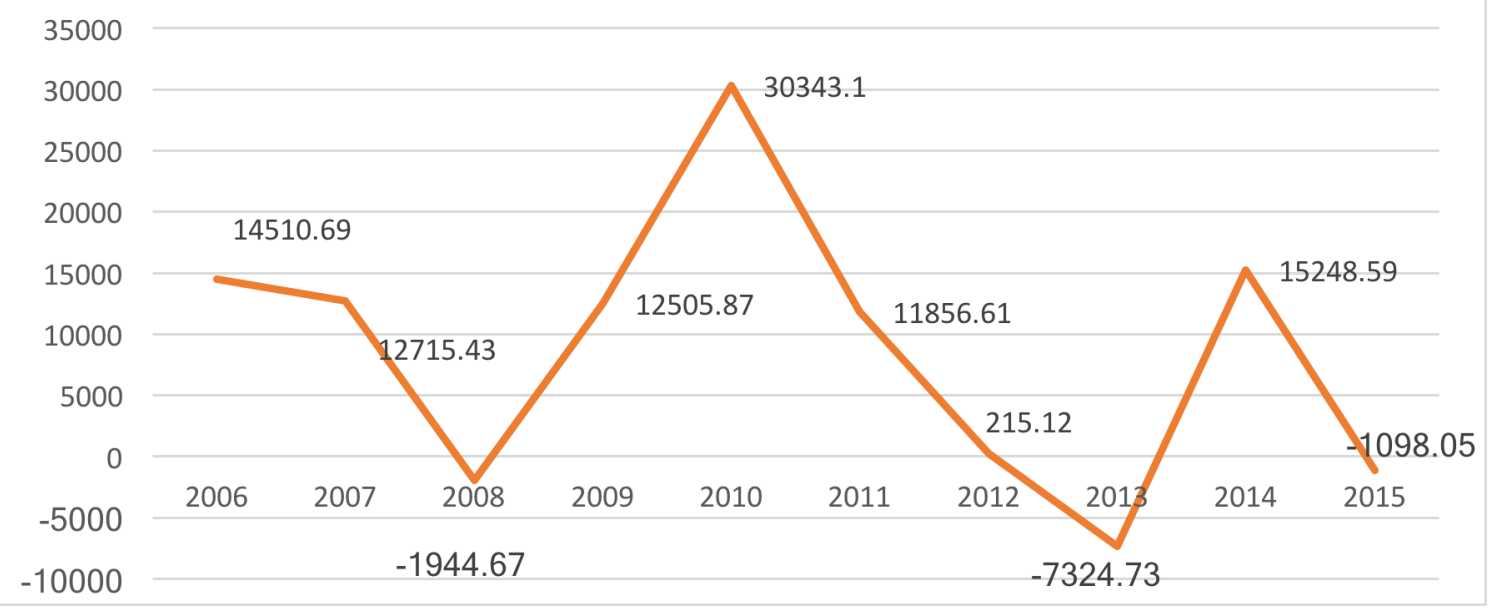

Figure 1 shows that the balance of payments from 2006 to 2015 experienced fluctuations, also seen a phenomenon that occurs, namely an adverse balance of payments deficit. In 2008 the balance of payments experienced a deficit of US \$1,944.67 billion; this was caused by the impact of the global crisis that began with the US financial crisis. In 2013 Indonesia's balance of payments experienced a deficit back to US $\$-7,324.73$ billion; this was due to weakening demand from trading partner countries, as well as weakening export commodity prices, which 
impacted declining export performance. On the other hand, imports still grew quite high, especially in the form of capital goods and raw materials, in line with the increasing investment activities (Bank Indonesia Report, 2013).

In 2015 the balance of payments deficit was US \$ -1,098.05 billion. Indonesia's 2015 balance of payments (BOP) experienced a slight deficit related to capital and financial transaction surplus, which could not fully finance the current account deficit. However, Indonesia's balance of payments deficit in 2015 was not too large in line with the significant improvement in the fourth quarter of 2015 (Bank Indonesia Report, 2015). These fluctuations raise the suspicion that there are links with several factors that influence and have been identified both from the monetary approach theory and research related to the Indonesian Balance of Payments.

According to the monetary approach theory (Krugman: 1992: 274), in various situations, the balance of payments problem is often a direct result of imbalances in the financial market so that the balance of payments problem must be addressed with appropriate monetary policy. Several factors can affect changes in the balance of payments according to the monetary approach, including real domestic income, domestic price levels, domestic interest rates, and domestic credit. The following is the development of Gross Domestic Product (GDP), Exchange Rate, and Inflation from 2010 to 2013 which is presented in table 1 as follows.

Table 1. Descriptive statistics of GDP, Exchange Rates and Inflation in 2010 - 2015

\begin{tabular}{|c|c|c|c|}
\hline Year & GDP & Exchange Rate & Inflation \\
\hline 2010 & $6,446,852$ & 100.23 & 5.13 \\
\hline 2011 & $7,422,781$ & 99.10 & 5.35 \\
\hline 2012 & $8,229,439$ & 93.84 & 4.28 \\
\hline 2013 & $9,083,973$ & 83.02 & 6.41 \\
\hline 2014 & $10,569,705$ & 91.33 & 6.39 \\
\hline 2015 & $11,531,717$ & 89.89 & 6.36 \\
\hline
\end{tabular}

Gross Domestic Product (GDP) is closely related to the Balance of Payments, but table 1 shows that an increase in GDP should be able to encourage an increase in the balance of payments in Indonesia, whereas in 2010-2015 the increase in GDP was not offset by an increase in the balance of payments, where Indonesia's balance of payments experienced decrease in a row, that the development of the exchange rate in Indonesia and the balance of payments of Indonesia illustrates the weakening of the exchange rate from 2010 to 2015. Likewise, the movements that occur with the balance of payments of Indonesia. This shows a direct relationship between the exchange rate and the development of Indonesia's balance of payments. While inflation from 2010 to 2015 experienced fluctuations. The Indonesian economy during 2010 was still confronted with several significant challenges, namely inflation which tended to increase to 7\%, substantial capital inflows, the existence of significant liquidity, problems in the banking sector, as well as various obstacles in the real sector.

\section{Balance of Payments}

\section{LITERATURE REVIEW}

Balance of payments is a balance sheet that contains data on export, import, and outflows of capital from and to a country. In other words, the balance of payments is a record of financial flows that shows the transaction value of trade and the flow of funds made by a country with another country in a particular year. The balance of payments can be divided into two parts, namely the current account and the capital account. (Supriana, 2008). According to Putong (2013), defining the balance of payment or Balance of Payment (BOP) is a record of a country's international economic transactions against other countries in a certain period (generally in a period of 1 year). This BOP will be seen as the ability/productivity of a country's population to 
the population of other countries that is reflected in the deficit or surplus of trade and capital out. Thus the balance of payments is a report compiled systematically containing all economic transactions concerning the productivity of a country's population and foreign residents within a specified period.

Deficits in the balance of payments have several adverse effects on the activities and stability of the country's economy. A deficit as a result of excessive imports will result in a decrease in domestic economic activity because consumers replace domestic goods with imported goods. The price of foreign exchange will increase and cause the prices of imported goods to become more expensive. Declining domestic economic activity reduces the enthusiasm of entrepreneurs to invest and develop new business activities.

According to Amalia (2007), classification of transactions in balance of payments includes :

1. Current Account. Consists of :
a. Merchandise/visible trade
b. Service/invisible trade
c. Capital results and donations
d. Gifts

2. Capital Account. Including :

a. Stand-alone capital, in the form of loans or foreign capital that is not to cover the balance of payments deficit.

b. Capital that does not stand alone, namely loans to cover the balance of payments deficit.

3. Gold Account

This account records all transactions that are separate from trade included in the current account because this gold account performs a particular monetary function in the banking system in most countries and the balance of payments.

\section{Errors and Omission}

a. Material balance: the balance that exists in material items means that the balance can be entirely covered by foreign exchange earnings.

b. Formal balance

Balance of payment accounts are a systematic procedure for measuring and summarizing all economic and financial transactions between residents of one country and residents of another country for a certain period.

The economic condition of a country can be seen both from the internal and external sides. The internal conditions of an economy are reflected in developments in the real sector (including production, consumption, exports, imports, and investment), the government sector (fiscal policy, national development budget) and developments in the monetary sector (including monetary and banking authorities). Meanwhile, external conditions were reflected in the development of the balance of payments. The development of the balance of payments has close links with developments in the real, fiscal and monetary sectors.

In general, transactions in the external sector recorded in the balance of payments are a picture of all resource flows, both money and goods, and services, whose ownership moves from one country to another. Transfer of ownership can occur due to exchange or without exchange (unrequited transfer), such as grants. Transactions that cause the flow of resources can be grouped into two categories. First, transactions related to trade, namely exports and 
imports of goods and services, transactions related to income, such as interest payments and dividends, and transactions related to transfers, such as grants. Second, transactions related to capital goods and investment, namely direct investment and portfolio investment. In the balance of payments, transactions in the first group are called current accounts, while transactions in the second group are called capital and financial transactions (Kuncoro, 2015).

\section{Gross Domestic Product}

According to Djohanputro (2008), Gross Domestic Product (GDP) is the total final value (in units of currency) of all final products, both in the form of goods and services in a country. Meanwhile, according to Silalahi (2014), gross domestic product is the number of products in the form of goods and services produced by production units within the territory of a country (domestic) for one year. The calculation of the value of GDP can be done on two types of price basis, namely GDP at current prices-is GDP calculated based on prices in effect in that year. GDP at current prices serves to see the dynamics/development of the real economic structure in the year, and GDP based on constant prices- is GDP calculated based on prices that apply in a particular year (Naf'an, 2014).

\section{Effect of Gross Domestic Product on Balance of Payments}

According to Masdjojo (2005), there is a positive relationship between income and the balance of payments. Assuming other factors are constant, any increase in income will cause an increase in the balance of payments balance. Changes in public income will affect the balance in the domestic money market. An increase in people's income will increase the demand for money. Likewise, in research, real GDP is one of the essential factors in influencing the balance of payments. Real GDP has a positive effect both in the short and long term. As we know, real GDP is the final value of goods and services produced in a year at the base price. If real GDP increases, exports increase, and the current account will become a surplus and, consequently, the balance of payments will increase as a whole.

\section{Exchange Rates}

According to Sukirno (2013), a foreign exchange rate can be defined as the amount of domestic money needed, which is the amount of rupiah needed to obtain one unit of foreign currency. Economists divide the exchange rate into two types, namely the nominal exchange rate-the value that someone uses when exchanging one country's currency with another country's currency, and the real exchange rate-the value that someone uses when exchanging goods and services from one country with goods and services from other countries. There are several exchange rate theories, among others:

1. Purchasing Power Parity Theory(PPP)

A traditional theory, this theory states that the prices of similar goods in other countries are under the prevailing exchange rate between countries. This theory is called The Law of One Price.

2. Elasticity Theory

Stating that the exchange rate is the price of foreign exchange to maintain a country's international balance of payments at an equilibrium level (Pinem, 2009).

\section{Effect of Rupiah Exchange Rates on Balance of Payments}

An increase in the exchange rate of a country can lead to lower prices of exported goods compared to imports; this condition will affect the ability to increase exports and decrease the ability of imports. If the ability of exports is higher than imports, then this will cause a surplus in Indonesia's balance of payments. Likewise, with the opinion of Mankiw (2006), that the real exchange rate between the two countries is calculated from the nominal exchange rate and the price level in both countries. If the real exchange rate is high, assuming foreign prices are fixed, 
then the prices of domestic goods are relatively higher than foreign prices. Domestic residents want to buy a lot of imported goods and foreigners will buy a little of our goods. Therefore, the amount of net domestic imports will increase, and net domestic exports will below. However, if the real exchange rate is low, assuming foreign prices are fixed, the prices of domestic goods are relatively lower than foreign prices. In this case, the domestic population will only buy a few imported goods, and foreigners will buy a wide variety of our products, so the amount of net domestic exports will increase, resulting in a balance of payments surplus. According to Sugema research (2005), that the exchange rate in Indonesia has a positive effect on the current account because the devaluation of the exchange rate will be able to encourage exports.

\section{Inflation}

According to Putong (2013), the increase in commodity prices, in general, is caused by the synchronization between the commodity procurement system program (production, pricing, and money printing) with the level of income owned by the community. Meanwhile, according to Zakaria (2009), inflation is an economic situation where the level of prices and general costs rise; for example rising rice prices, fuel prices, car prices, labor costs, land prices, rental of capital goods.

\section{Influence of Inflation on the Balance of Payments}

High inflation can harm a country's economy. Where if there is an increase in inflation, it will cause the ability of exports to be lower than the ability of imports. This will cause a deficit in Indonesia's balance of payments, which will later negatively affect Indonesia's balance of payments. This is in line with Mavi (2014) that inflation harms the balance of payments.

\section{METHODOLOGY}

The scope of this research is focused on gross domestic product, the exchange rate of the rupiah, and inflation on the balance of payments in Indonesia in the period 1997-2015. In this study, it will be seen the impact of gross domestic product, the exchange rate of the rupiah, and inflation on the balance of payments in Indonesia. The data used in this study are secondary data, which is data obtained indirectly from the period 1995 to 2015. Data sources were obtained from Bank Indonesia and the Central Statistics Agency. The data collection method used in this study is the indirect method, which is documentation through recording or copying data from Bank Indonesia and the Central Bureau of Statistics.

\section{Data Analysis Model: \\ $A R D L-E C M$}

ARDL is the least square regression, which at least contains lag of the dependent variable and explanatory variables. ARDL is usually denoted by the ARDL notation ( $p, q 1, \ldots q k)$, where $p$ is the number of lag dependent variables, $q 1$ is the number of lags from the first explanatory variable, and $\mathrm{qk}$ is the number of lags from the next explanatory variable k. ARDL model as follows:

$$
Y t=\alpha Y t=\sum_{i=1}^{p} y i y t-i+\sum_{j=1}^{k i} \sum_{i=0}^{q j} X j, t-i^{\prime} \beta j, i+\epsilon t
$$

Some explanatory variables, $\mathrm{Xj}$, may not have the term left in the model ( $q \mathrm{j}=0$ ). This variable is called fixed or static regressors. An explanatory variable with at least one Lag is called dynamic regressors. To determine the ARDL model, it must determine how much lag of each variable that must be entered (ie determine p and q1, ..., qk) (Ekananda, 2016). 
Based on the ARDL cointegration test approach and using Error Correction Model (ECM) which is a version or derivative of ARDL on the Balance of Payments Determinants in Indonesia.

Thus the formulation of the Indonesian balance of payments model is as follows:

$$
N P I_{t}=\mathrm{f}\left(\mathrm{GDPt}, \mathrm{ER}_{\mathrm{t}}, \mathrm{Inf}_{\mathrm{t}}\right)
$$

The model above is then formed into a multiple linear regression equation:

$$
N P I_{t}=\beta_{0}+\beta_{1} G D P_{t}+\beta_{2} K U R S_{t}+\beta_{3} I n f_{t}+\varepsilon_{t}
$$

The balance of payment function is converted into the natural logarithmic form as follows :

$$
L n N P I_{t}=\beta_{0}+\beta_{1} \operatorname{LnGDP} P_{t}+\beta_{2} L n K U R S_{t}+\beta_{3} I n f_{t}+\varepsilon_{t}
$$

explanation:

BOP = Indonesia's Balance of Payments

GDP $=$ Gross Domestic Product

$\mathrm{ER}=$ Exchange rates

Inf = Inflation

Ln = Natural logarithm

$\beta_{0} \beta_{1} \beta_{2} \beta_{3}=$ Estimation Parameters

$\mathrm{t}=$ Time Series Data

$\varepsilon_{t}=$ Error Term

If cointegration occurs, the problem of direct regression will disappear. In circumstances where the dependent and independent variables are not stationary but are integrated, the appropriate model used is the ECM (Error Correction Model). Meanwhile, if not cointegrated, the model used is the ARDL model. Based on, the ARDL cointegration approach by estimating the ECM from the ARDL model for Indonesia's Balance of Payments Determinants is transformed as follows :

$\mathrm{BOP}_{\mathrm{t}}=\alpha_{0}+\sum_{i=1}^{P} \emptyset_{i} \Delta(N P I)_{t-i}+$

$\sum_{i=0}^{p} \theta_{i} \Delta \ln (N P I)_{t-i}+\sum_{i=0}^{p} \beta_{i} \Delta \ln (K U R S)_{t-i}+\sum_{i=0}^{p} \varphi_{i} \Delta \ln (\operatorname{Inf})_{t-i}+\delta_{1}(N P I)_{t-1}+$

$\delta_{2} \ln (P D B)_{t-1}+\delta_{3} \ln (K U R S)_{t-1}+\delta_{4} \ln (\operatorname{Inf})_{t-1}+\mu_{t}$

Explanation:

BOP = Indonesia's Balance of Payments

GDP $=$ Gross Domestic Product

$\mathrm{ER}=$ Exchange rates

Inf = Inflation

Ln = Natural logarithm

$\Delta$ : Previous comparison (change)

$\mathrm{p}$ : lag length optimize

$\mathrm{t}-1$ : past value

If there is a long-term relationship (cointegration) of variables, the long-term model can be estimated as follows:

$$
\begin{aligned}
& \mathrm{BOP}_{\mathrm{t}}=\alpha_{1}+\sum_{i=1}^{P} \emptyset_{1 i}(N P I)_{t-5}+\sum_{i=0}^{p} \theta_{1 i} \ln (P D B)_{t-5}+ \\
& \sum_{i=0}^{p} \beta_{1 i} \ln (K U R S)_{t-5}+\sum_{i=0}^{p} \varphi_{1 i} \ln (\operatorname{Inf})_{t-5}+\mu_{t}
\end{aligned}
$$


Specifications The ARDL approach of short-term dynamics can be derived by forming the ECM (Error Correction Model) model as follows :

$\mathrm{BOP}_{\mathrm{t}}=\alpha_{2}+\sum_{i=1}^{P} \emptyset_{2 i} \Delta(N P I)_{t-i}+\sum_{i=0}^{p} \beta_{2 i} \Delta \ln (P D B)_{t-i}+$

$\sum_{i=0}^{p} \varphi_{2 i} \Delta \ln (K U R S)_{t-i}+\sum_{i=0}^{p} \beta_{2 i} \Delta \ln (\operatorname{Inf})_{t-i}+\psi E C M_{t-1}+\vartheta_{t}$

Explanation : $E C M_{t-1}$ is an error fault, defined as follows:

$E C M_{t}=(\mathrm{BOP})_{t}-\alpha_{1}-\sum_{i=0}^{p} \theta_{1 i} \ln (P D B)_{t-i}-\sum_{i=0}^{p} \beta_{1 i} \ln (K U R S)_{t-i}-$ $\sum_{i=0}^{p} \varphi_{1 i} \ln (\operatorname{Inf})_{t-i}$

If in equations (1) Y and X present the logarithm of the explanatory variables, then in equations (2) $\Delta \mathrm{Y}$ and $\Delta \mathrm{X}$ will present changes in the explanatory variable log. However, a change in the log variable is a relative change or percentage change (Gujarati, 2012).

\section{Data Stationary Testing}

The stationary test is conducted because non-stationary data has autocorrelation or heteroscedasticity, which will result in unfavorable estimation models (Nachrowi and Usman, 2006). Stationarity tests can be performed using graph models, correlograms, and unit-roots. Unit root tests can be distinguished from the Dickey Fuller Test and the Philip Peron Test.

\section{Determination of Optimal Lag Length}

Determination of the optimum Lag aims to choose how much the amount of lag that will be used for research. So that the selection of the optimum amount of lag is needed in obtaining better results. According to (Ekananda, 2015), determining the maximum lag of cointegration testing is used Akaike Information Criteria (AIC) and Schwarz's Bayesian Information Criteria (SBC).

\section{Cointegration Testing}

According to Ekananda (2015), cointegration is a concept in econometrics that shows the phenomenon of harmony/slope of several data fluctuations in a certain period. This test is used to anticipate that macro variables with time-series data usually have stationarity problems. Through cointegration analysis, it is expected that there is a long-term relationship between the independent variable and the dependent variable, which is usually not stationary for time series data, it can be analyzed. Besides, the method used with the ARDL cointegration test approach in this study to see the level of significance in the F-statistics value is the Bounds test.

\section{Engle-Granger Cointegration Test 9 (EG)}

To do the Engle-Granger (EG) cointegration test, you must first regress the long-term equation and then get the residual (Ekananda, 2015). From this residual then test with DF and ADF.

\section{Durbin Watson's Regression Cointegration Test}

In this test, the Durbin-Watson $\mathrm{d}$ value obtained from the equation, with the null hypothesis $\mathrm{d}$ $=0$ is no longer $d=2$. Based on the simulation, the critical value with $\alpha=1 \% ; \alpha=5 \% ; \alpha=10 \%$. If the calculated value $d$ is greater than the critical value then the data is cointegrated, and vice versa means there is no cointegration (Widarjono, 2013).

\section{Johansen's Cointegration Test}

To find out the presence or absence of cointegration, a Johansen test was conducted. According to Widarjono (2013), the test developed by Johansen can be used to determine the 
cointegration of several variables (vectors). Johansen's cointegration test can be seen from the trace statistic analysis and the critical value at the level of confidence $\alpha=5 \%$. Johansen's test uses trace statistic analysis with a critical value at the level of confidence $\alpha=5 \%$ or $1 \%$. If the trace statistic value is smaller than the critical value at the $5 \%$ and $1 \%$ confidence level, then it is concluded that the variable is not cointegrated.

\section{ARDL Cointegration Test Approach (ARDL Approach to Co-Integration)}

In the ARDL method, the unit root test is not mandatory. However, it is still a good idea to ensure that the data used are not (I) or stationary at the second difference level. The root unit test will be carried out with the Philips-Perron (PP) Test. The advantage of the Phillips-Perron Test measurement compared with the Augmented Dickey-Fuller (ADF) test is that the PP Test incorporates elements of structural changes that occur in the data. Through this test it will be known whether there is cointegration or not, as well as the direction of cointegration. The proof is done by comparing the F statistic greater than the level of significance of the various levels of trust, but cointegration occurs. However, on the contrary, if the statistical $F$ value is smaller than the significance level of the various levels of trust, then cointegration does not occur.

Thus the hypothesis in this model is :

HO : (no long term relationship)

H1: one of the coefficients $\beta \neq 0$ (there is a long-term relatiionship).

Hypothesis $\mathrm{HO}$ shows that between the dependent variable and the independent variable, in the long run, there is no cointegration relationship, and H1 shows that there is a cointegration relationship between the variables owned. There are advantages to the ARDL-based cointegration test when compared to the Johansen cointegration test. Johansen's cointegration test cannot be used to find out which variables are dependent and which are independent variables, but can only be used to find out how many cointegration equations are. In addition, with this cointegration test, each time series data does not need to pass the data stationarity test and may have different degrees of integration. So by doing this test the direction of cointegration can be known.

\section{Analysis of the Coefficient of Determination $\left(R^{2}\right)$}

To find this out, a method must be used to measure how close the regression line is estimated to the data. The size commonly used for this purpose is Goodness of Fit (R2). This Goodness of Fit measure reflects how much variation of the regressand (Y) can be explained by the regressor $(X)$. If $R 2=0$, it means that the variation of $Y$ cannot be explained by $X$ at all. Meanwhile, if $\mathrm{R} 2=1$, it means that the variation of $\mathrm{Y}, 100 \%$ can be explained by $\mathrm{X}$. In other words, if R2 $=1$, then all observation points are on the regression line. Thus, the size of the Goodness of Fit of a model is determined by R2 whose value is between zero and one (Nachrowi and Hardius, 2002).

\section{Explanation}

TSS : Total Sum of Squares

ESS : Explained of Sum Squared

RSS : Residual of Sum Squared

$$
\mathrm{R}^{2}=\frac{E S S}{T S S}
$$

The exact point on the regression line is caused by the presence of other factors that influence the independent variable. If there are no deviations, of course there will be no errors. As a result of this, then RSS $=0$, which means ESS $=$ TSS or R2 $=1$. Or in other words, all observation 
points are right on the regression line. So, TSS is actually a variation of the data, while ESS is a variation of the regression line created (Nachrowi and Hardius, 2002).

\section{Statistical Partial Test (T-test)}

The statistical t test basically shows how far the influence of one explanatory / independent variable individually in explaining the variation of the dependent variable (Ghozali, 2013). That is to prove the significance of the relationship between the independent variables and partially dependent variables. For testing this significance, the calculated $t$ value is compared with the $t$ table value at a certain level of confidence and degree of freedom. Before conducting the test, a hypothesis is usually made first, which for the t-test is usually shaped :

HO : $\beta=0$

H1: $\beta \neq 0$

This means that based on available data, testing of $\beta$ (population regression coefficient) will be done, is it equal to zero, which means it has no significant effect on the dependent variable, or it is not equal to zero, which means it has a significant effect. (Nachrowi and Hardius, 2002).

\section{Simultaneous Statistical Test (F-test)}

The F statistical test basically shows whether all independent or independent variables entered in the model have a joint influence on the dependent variable. The null hypothesis (H0) to be tested is whether all parameters in the model are equal to zero, or:

$\mathbf{H}_{0}: \mathrm{b}_{1}=\mathrm{b}_{2}=\ldots \ldots . . .=\mathrm{bk}=0$

That is, whether all independent variables are not a significant explanation of the dependent variable. The alternative hypothesis (HA) is that not all parameters are simultaneously equal to zero, or:

$\mathrm{H}_{\mathrm{a}}: \mathrm{b}_{1} \neq \mathrm{b}_{2} \neq \ldots \ldots \ldots \ldots \mathrm{bk} \neq 0$

That is, whether all independent variables are not a significant explanation of the dependent variable. The alternative hypothesis (HA) is that not all parameters are simultaneously equal to zero, or (Ghozali, 2013).

\section{RESULT}

Developments in Indonesia's Balance of Payments during the period 1997 - 2015 experienced fluctuating developments. This can be seen from the data obtained from the Indonesia balance of payments report published by Bank Indonesia, in 1997-1998 Indonesia's balance of payments experienced an increase of 2,123 but in 1999 it had decreased by 2,080. Then in 2000 it increased and also in 2002 it also increased to 5,027. but in 2003 it decreased to 3,655, - and in 2005 the balance of payments also decreased by 444, -. Conducive developments in the global economy in 2010 supported the performance of Indonesia's Balance of Payments (BOP). In the reporting year, BOP recorded a sizeable surplus of US $\$ 30.3$ billion, both from current and capital and financial transactions. Exports recorded high growth so that they were able to maintain a current account surplus amid imports and sharply increased income transfer payments. Meanwhile, along with the strong inflows of foreign capital, the capital and financial account has recorded a substantial surplus with an improved composition. This is reflected in the strong inflows of foreign capital in the form of direct investment (FDI) which increased sharply, in addition to investments in the form of portfolios which also increased quite significantly (Bank Indonesia, 2010).

This study began by conducting a stationarity test of the variables used in the study. It is important to use ARDL and ECM to find out whether or not there are variables which are not 
stationary at the level of level. In this study, the unit root test was carried out with the ADF and PP tests. Whereas in the ADF and PP test there is one variable which is stationary.

Table 2. Stationary Unit Root Test Results (ADF Test)

\begin{tabular}{|c|c|c|c|c|}
\hline No & Variabel & $\begin{array}{c}\text { ADF value } \\
\text { T-Statistic }\end{array}$ & Prob*. ADF & Interpretation \\
\hline \multicolumn{5}{|c|}{ Level } \\
\hline 1. & LNBOP & -1.503659 & 0.1205 & Unstationary \\
\hline 2. & LNGDP & 8.137118 & 1.0000 & Unstationary \\
\hline 3. & INF & -2.015276 & 0.0451 & Stationary \\
\hline 4. & E & 0.845911 & 0.8835 & Unstationary \\
\hline \multicolumn{5}{|c|}{ First Difference } \\
\hline 1. & D(LNBOP) & -7.400500 & 0.0000 & Stationary \\
\hline 2. & D(LNGDP) & -2.664180 & 0.0110 & Stationary \\
\hline 3. & D(E) & -5.438017 & 0.0000 & Stationary \\
\hline
\end{tabular}

The Dickey-Fuller test at the level above shows one of the stationary variables, but some variables are not stationary with a probability level above $\alpha=0.05$. So the variables used in this study were stationary at the first difference degree. The t-statistic ADF value of Indonesia's balance of payments (INBOP), GDP (INGGDP), inflation (INInF) and ER (E) in sequence, namely $-7.400500,-2.664180,-2.015276$ and -5.438017 . based on the table above can be seen with a probability value smaller than $\alpha=0.05$ so it can be said that $\mathrm{HO}$ is rejected and $\mathrm{Ha}$ is acceptable.

Determination of the optimum Lag is a way to choose how much the amount of lag that will be used in research. So that the selection of the optimum amount of lag is needed to obtain better results. Based on Pesar et al. (2001), in determining the maximum lag of cointegration testing the Akaike Information Criteria (AIC) and Schwarz's Bayesian Information Criteria (SBC) are used.

Table 3. Optimal Lag-length Determination Results

\begin{tabular}{|c|c|c|c|c|c|c|}
\hline Lag & LogL & LR & FPE & AIC & SC & HQ \\
\hline 0 & -166.9639 & NA & 6389.648 & 20.11340 & 20.30945 & 20.13289 \\
\hline 1 & -102.8693 & 90.48650 & 23.93408 & 14.45521 & 15.43546 & 14.55265 \\
\hline 2 & $\mathbf{- 7 0 . 2 8 8 3 5}$ & $\mathbf{3 0 . 6 6 4 4 1}^{*}$ & $\mathbf{5 . 1 1 5 7 7 8}^{*}$ & 12.50451* $^{*}$ & 14.26896* $^{*}$ & 12.67990* $^{*}$ \\
\hline
\end{tabular}

From table 3 above shows that there is an asterisk $\left(^{*}\right)$, which is in the third lag with the sequentially modified LR test statistic (LR) indicator. In addition, there are also asterisks with Final Prediction Error (FPE) indicators, Akaike information criterion (AIC), Schwarz information criterion (SC), and Hannan-Quinn information criterion (HQ) and the most asterisks $\left(^{*}\right)$ are found in the third lag. Then it can be concluded that the Optimal lag-length is in the third lag.

\section{ARDL Testing Results and Interpretation}

To get an illustration of the effects of long-term and short-term dynamics of each of the determinants of savings in Indonesia, a test can be performed using the ARDL-Bound cointegration test approach and if it is proven that there is a long-term cointegration relationship, so that long-term coefficient estimates for the model can be estimated ARDL ( $p, q)$ that can be estimated (Ekananda, 431: 2015). If it proves to be a cointegration relationship, then get an error correction representation from the selected ARDL model after estimating the long-term coefficient. Error Correction Model is an ARDL model that has been expanded with 
an error correction term. Next estimation for the long term model. Estimation results on the long-term model can be seen in table 4 below.

Table 4. ARDL Estimation Results Long-Term Coefficient

\begin{tabular}{|c|c|c|c|c|}
\hline \multicolumn{5}{|c|}{ Long Run Coefficients } \\
\hline Variable & Coefficient & Std. Error & t-Statistic & Prob. \\
\hline LnGDP & -7.149376 & 1.450486 & -4.928954 & 0.0003 \\
\hline INF & -0.144326 & 0.067820 & -2.128091 & 0.0530 \\
\hline E & 0.413222 & 0.112080 & 3.686854 & 0.0027 \\
\hline C & 79.695254 & 16.692601 & 4.774286 & 0.0004 \\
\hline R-squared & 0.691665 & & & 2.225419 \\
\hline F-statistic & 7.290473 & Durbin-Watson stat & & \\
\hline Prob (F-statistic) & 0.002622 & & & \\
\hline
\end{tabular}

If in equation (1) chapter 3 the variables $\mathrm{Y}$ and $\mathrm{X}$ present the logarithm of the explanatory variables, then in equation (2) $\Delta \mathrm{Y}$ and $\Delta \mathrm{X}$ will present the changes in the explanatory variable log. However, a change in the log variable is a relative change or percentage change (Gujarati, 14: 2012). However, for variable data that uses minus, it cannot use a double log (log-log). Based on table 4 above shows that in the long run the independent variable Gross Domestic Product (lnGDP) has a negative and significant effect, but Inflation (INF) has an insignificant negative effect on the Balance of Payments in Indonesia, while ER (E) has a significant positive effect on Balance of Payments in Indonesia in the long run.

The long-term estimation results of the ARDL (Autoregressive Distributed Lag) model.

$$
\text { LNBOP }=79.695254-7.149376^{*}(\operatorname{lnGDP})-0.144326^{*}(\mathrm{INF})+0.413222^{*}(\mathrm{E})
$$

\section{ECM Testing Results and Interpretation}

The next test is to estimate the short-term coefficient by using the Error Correction Model (ECM). Error Correction Term (ECT) is obtained from the long-term coefficient test, which was carried out in the previous stage. Where is the short-term coefficient is speed of adjustment. Estimates will be made which can be seen in table 5 below.

Table 5. ECM Short Term Estimation Results

\begin{tabular}{|c|r|r|r|c|}
\hline Variable & Coefficient & Std. Error & t-Statistic & Prob. \\
\hline C & -2.552293 & 5.024603 & -0.507959 & 0.6207 \\
\hline D(lnGDP) & 6.924443 & 32.54967 & 0.212735 & 0.8351 \\
\hline D(INF) & -0.077930 & 0.132835 & 0.586672 & 0.5683 \\
\hline D(E) & 0.556307 & 0.187726 & 2.963407 & 0.0118 \\
\hline ECT(-1) & -1.544918 & 0.422050 & -3.660509 & 0.0033 \\
\hline
\end{tabular}

The estimation results above show that there is a short-term cointegration relationship between the ER variable and the Balance of Payments in Indonesia. This can be seen from the coefficient value of ECT $(-1)$, which is negative and significant. Short Term Estimation Results Error Correction Model.

$\mathrm{D}(\mathrm{LNBOP})=-2.552293+6.924443 * \mathrm{D}(\operatorname{lnGDP})-0.077930 * \mathrm{D}(\mathrm{INF})+0.556307 * \mathrm{D}(\mathrm{E})-$ $1.544918 *$ ECT(-1)

From the estimation results above, the short-run model of the Gross Domestic Product variable (lnGDP) has a positive but not significant effect, and inflation (INF) has a negative but not 
significant effect on the Balance of Payments in Indonesia in the short term. In this short-term analysis, the independent variable, ER (E), has a significant positive effect on the Balance of Payments in Indonesia and has an R-squared of 0.744955. This means that the independent variable can explain the dependent variable by $74 \%$, and other variables outside the model explain the rest. This is proven by the F-statistic probability of 0.001505 , which is smaller than the $5 \%$ significance level..

\section{CONCLUSIONS}

Based on the regression results for the long-term Autoregressive Distributed Lag Model (ARDL) and Error Correction Model (ECM) regarding the effect of independent variables such as Interest Rates, Gross Domestic Product and Inflation Against Savings dependent variables in Indonesia, several conclusions can be presented, namely from several independent variables that are tried and included in the savings equation in Indonesia using the Autoregressive Distributed Lag Model (ARDL) for the long run and Error Correction Model (ECM) for the short run, namely the variable gross domestic product, inflation rate, and ER. In the long run there are 2 (two) significant variables, namely gross domestic product and ER. While inflation is not significant. For the short term, there is 1 (one) significant variable, namely ER. Thus, only the ER variable is significant in both the long and short term. With only 1 (one) significant independent variable both in the long term and short term, it can be concluded that ER in the long term and short term is the main determining factor affecting the Balance of Payments in Indonesia. Independent variables such as Gross Domestic Product and ER on the dependent variable Balance of Payments in Indonesia, in the long run, have a significant influence on the dependent variable Balance of Payments. While in the short term, the ER variable has a significant effect and for other independent variables such as the GDP variable, and the inflation rate does not have a significant effect. The influence of independent macroeconomic variables on the savings dependent variable, obtained the coefficient of determination (RSquare) in the long run that is equal to 0.691665 or equal to $(69.16 \%)$ and in the short term the coefficient of determination (R-Square) is obtained in the short term is 0.744955 or (74.49\%), so that in the short and long term that is equal to $69.16 \%$ and $74.49 \%$ the variation in the variable changes in the Balance of Payments in Indonesia can be explained by variables of gross domestic product, inflation and ER. While the rest in the long and short term by $30.84 \%$ and another $25.51 \%$ is explained by variables outside the model (which are not examined).

\section{References}

Amalia, Lia. 2007. Ekonomi Internasional. Edisi Pertama. Cetakan Pertama. Graha Ilmu: Yogyakarta

Basri, Faisal. 2010. Dasar-dasar Ekonomi Internasional. Prenada Media Group : Jakarta

Basuki, Agus Tri dan Prawoto, Nano. 2016. Analisis Regresi dalam Penelitian Ekonomi \& Bisnis. Cetakan Pertama. PT Rajagrafindo Persada: Jakarta

Djohanptro, Bramantyo. 2008. Prinsip-prinsip Ekonomi Makro Praktis untuk Mahasiswa dan Pebisnis. Penerbit PPM. Jakarta

Ekananda, Mahyus. 2015. Ekonometrika Dasar Untuk Penelitian Dibidang Ekonomi, Sosial dan Bisnis. Mitra Wacana Media. Jakarta

Ekananda, Mahyus. 2016. Analisis Ekonometrika Time Series. Edisi 2. Mitra Wacana Media: Jakarta

Ghozali, Imam. 2013. Aplikasi Analisis Multivariate dengan Program IBM SPSS 21. Cetakan ke tujuh. Penerbit Undip : Semarang.

Gujarati, Damodar N and Porter, Dawn C. 2012. Dasar-dasar Ekonometrika. Jilid 2. Mc Graw Hill, Salemba Empat. Jakarta.

Kuncoro, Mudrajad. 2015. Mudah Memahami dan Menganalisis Indikator Ekonomi. UPP STIM YKPN: Yogyakarta Mankiw, N. Gregory. 2006. Makroekonomi (Terjemahan), Edisi Keenam. Penerbit Erlangga : Jakarta. 
Masdjojo, G, N. 2005. Analisis Fenomena Moneter Neraca Pembayaran Indonesia : Suatu Studi Tentang FaktorFaktor Yang Mempengaruhinya Periode 1980-2003, Tesis. Universitas Diponegoro : Semarang.

Mavi, Anupreet Kaur and Nishi Sharma. 2014. Macro-Economic Determinants on Balance Of Payment In India. International Journal of Science and Research (IJSR). Vol 2

Nachrowi, D. Nachrowi dan Hardius Usman. 2002. Penggunaan Teknik Ek

onometri. PT RajaGrafindo Persada: Jakarta

Laporan Perekonomian Indonesia berbagai edisi. Jakarta : Bank Indonesia.

Nachrowi, D. Nachrowi dan Hardius Usman. 2006. Pendekatan Populer dan Praktis Ekonometrika untuk Analisis Ekonomi dan Keuangan. LPFE-UI

Naf'an. 2014. Ekonomi Makro Tinjauan Ekonomi Syariah. Yogyakarta. Graha ilmu

Putong, Iskandar. 2013. Economics Pengantar Mikro dan Makro. Edisi 5. Jakarta. Mitra Wacana Media

Silalahi, Remus, dkk. 2013. Teori Ekonomi Makro. Bandung. Cita Pustaka Media Perintis

Sugema, Iman. 2005. The Determinants of Trade Balance and Adjusment to the Crisis in Indonesia. Centre Economics Studies

Sukirno, Sadono. 2013. Makro Ekonomi Teori Pengantar. Jakarta. PT Raja Grafindo Persada

Supardi. 2013. Aplikasi Statistika Dalam Penelitian Konsep Statistika Yang Lebih Komprehensif. Edisi Revisi. Change Publication: Jakarta Selatan

Supriana, Tavi. 2008. Ekonomi Makro. USU PRESS: Medan

Tijani, Julius 0. 2014. Empirical Analysis of Balance of Payment Adjustment Mechanisms : Monetary Channel in Nigeria, 1970-2010. Mediterranean Journal of Social Sciences. Vol 15 No 14

Thoifah, I'anatut. 2015. Statistika Pendidikan dan Metode Penelitian Kuantitatif. Penerbit Madani: Malang

Widarjono, Agus. 2013. Ekonometrika Pengantar dan Aplikasinya. UPP STIM YKPN: Yogyakarta

Zakaria, Junaiddin. 2009. Pengantar Teori Ekonomi Makro. Gaung Persada (GPPress): Jakarta. 